\title{
VEŘEJNOPRÁVNÍ SOUHLASY V REŽIMU STAVEBNÍHO ZÁKONA
}

\author{
PETR PRŮCHA
}

Abstract: Public-law Approvals under the Building Act

The paper deals with the so-called public-law consents in the regime of the Building Act, as simplified forms of activity, resp. decision-making, building offices. It points out the development of this amendment since its adoption in 2007 and its current status. At the same time it also points to the development of related case law of administrative courts, including its most recent conclusions. The paper concludes that the development of the current state of the legal regulation of public consent and related case law can be considered as the most adequate.

Keywords: territorial consent; joint territorial consent and consent to the execution of the announced building plan; approval to the execution of the announced building plan; occupancy permit; approval to change the use of the building; consent to the removal of construction; unlawful intervention; decision; judicial review

Klíčová slova: územní souhlas; společný územní souhlas a souhlas s provedením ohlášeného stavebního záměru; souhlas s provedením ohlášeného stavebního záměru; kolaudační souhlas; souhlas se změnou v užívání stavby; souhlas s odstraněním stavby; nezákonný zásah; rozhodnutí; soudní přezkum

DOI: $10.14712 / 23366478.2020 .10$

\section{1. ÚVODEM}

Verejnoprávni souhlasy v režimu stavebního zákona jsou ve stávajícím pojetí ve smyslu platné právní úpravy specifickými, zjednodušujícími, aplikačními formami realizace veřejné správy. Ve své podstatě jsou jednou z vícerých forem rozhodování stavebních úřadů $\mathrm{v}$ širším slova smyslu, ${ }^{1}$ a jako takové představují typovou podmnožinu představitelných forem činnosti veřejné správy.

To souvisí s tím, že stávající stavební zákon ${ }^{2}$ již při svém přijetí nastavil pro rozhodování stavebních úřadů, na rozdíl od úpravy předchozí, diferencované spektrum jeho způsobů, které se vzájemně liší jak co do obsahu, tak i co do výrazových forem navenek. Smyslem a cílem tohoto záměru bylo nabídnout př́ílušně „,rozdílné“ nástroje rozhodování, především s ohledem na rozdílnou míru složitosti posuzovaných otázek,

1 Např. rozhodnutí ve zjednodušeném územním řízení, uzavírání veřejnoprávních smluv namísto územních rozhodnutí čí stavebních povolení, apod. Tyto další formy činnosti a jejich využití v režimu stavebního zákona však nejsou předmětem zájmu tohoto příspěvku.

2 Zákon č. 183/2006 Sb., o územním plánování a stavebním řádu (stavební zákon), ve znění pozdějších předpisů (dále jen „stavební zákon“). 
a ve spojení s tím také preferovat v úvahu přicházející jednodušší, resp. zjednodušující, adekvátní postupy. ${ }^{3}$

Podle aktuálního právního stavu tak stavební zákon z tzv. veřejnoprávních souhlasů nabízí, při splnění předepsaných zákonných podmínek, k využití územní souhlas (§96), společný územni souhlas a souhlas s provedením ohlášeného stavebního záměru (§ 96a), souhlas s provedením ohlášeného stavebního záměru (§106), kolaudační souhlas (§ 122), souhlas se změnou v uživáni stavby (§ 127) a souhlas s odstraněním stavby (§ 128). S výjimkou společného územního souhlasu a souhlasu s provedením ohlášeného stavebního záměru přitom stavební zákon s ostatními veřejnoprávními souhlasy počítá již od počátku své účinnosti, zatímco uvedený společný souhlas je výsledkem teprve pozdější novelizace stavebního zákona.

Současně je nutno poznamenat, že i režimy všech ostatních veřejnoprávních souhlasů byly přirozeně průběžně novelizovány. Přímé dopady na úpravu veřejnoprávních souhlasů $\mathrm{v}$ podmínkách stavebního zákon přitom přinesly především zákon č. 350/2012 Sb., s účinností od 1. 1. 2013, a dále potom zákon č. 225/2017 Sb., s účinností od 1. 1. 2018.

Právní úprava přitom po celou dobu, s dílčími nuancemi, pojímala, a i nyní pojímá, dané veřejnoprávní souhlasy jako správní úkony, přicházející v úvahu namísto rozhodnutí na př́slušných věcných úsecích, čemuž koresponduje i to, že po obsahové i formální stránce je od samého počátku koncipuje zcela jinak než správní rozhodnutí. Stejně tak i zákonem předepisovaná procedura vydání daných souhlasů není, na rozdíl od procedury vydání jinak v úvahu přicházejících rozhodnutí, správním řízením, což má mj. ten důsledek, že dotčené osoby nevystupují jako účastníci řízení, a, jak lze dovodit z kontextu dané úpravy, proti vydaným souhlasům se také nelze odvolat.

Veřejnoprávni souhlasy $\mathrm{v}$ režimu stavebního zákona, které jsou předmětem bližšího zájmu v tomto př́spěvku, jsou ve své podstatě, ve spojení s připomenutými formami činnosti veřejné správy, podtypem individuálních správnich akti̊, jakožto aktů autoritativní aplikace správního práva. To souvisí s tím, či je výrazem toho, že individuální správní akty nemusí být vždy výsledkem jinak pro ně typického správního řizení, ale mohou být i vyústěním nejrůznějších jednodušších procedur ve veřejné správě, a v takových př́ípadech proto také nemívají ani formu správního rozhodnutí (jinak vlastní výsledečným produktům správního ř́zení).

Rozmanitost forem činnosti veřejné správy pro potřeby subjektivizace správního práva, a nakonec i její podstaty, je mj. reflexí toho, že př́slušný obsah, resp. účel, může být př́íp. sledován a dosažen, s ohledem na rozdílné (někdy ale také i obdobné) podmínky vždy dané věci, rozdílnými úkony či akty, které se od sebe liší svojí vnější formou, a také zpravidla i př́slušnou procedurou, jež jejich přijetí, resp. vydání, předchází. Takovou diferenciací je přitom sledována možnost vždy volit ty formy činnosti, které jsou nejadekvátnější faktické složitosti či obsažnosti řešených otázek v tom kterém případě.

3 Těmito veřejnoprávními souhlasy je tak zcela konkrétně sledován a naplňován záměr stavebního zákona vyjádřený v jeho úvodních ustanoveních, kde se v § 4 odst. 1 výslovně stanoví, že „Orgány územního plánování a stavební úřady přednostně využívají zjednodušující postupy a postupují tak, aby dotčené osoby byly co nejméně zatěžovány...". 
Tato diferenciace forem činnosti je potom současně provázena i diferenciací ve vnímání rozdílností tzv. materiálního a formálního nazírání na znaky těchto souhlasů jako správních aktů, což se $\mathrm{v}$ př́padě předmětných veřejnoprávních souhlasů částečně odrazilo ve změnách jejich právní úpravy, a dále zejména pak v jejich reflexi ve správně-soudní judikatuře.

$\mathrm{V}$ důsledku toho pak $\mathrm{v}$ uplynulých letech byla, a i nadále je, problematika těchto veřejnoprávních souhlasů jako specifických forem činnosti veřejné správy předmětem zvýšeného odborného zájmu jak z pohledu správní i správně-soudní praxe, tak také z pohledu teorie. Tato nesporná ,živost“", či trvající aktuálnost, tohoto tématu tak byla, či je, také důvodem $\mathrm{k}$ tomuto př́ispěvku. Jeho smyslem je především na dané problémy poukázat, zaujmout $\mathrm{k}$ nim vlastní postoj, ${ }^{4}$ a současně dále také podnítit příp. další odbornou diskusi $\mathrm{k}$ nim. Text prríspěvku bude tedy $\mathrm{v}$ dalším zaměřen na ty otázky či aspekty předmětných veřejnoprávních souhlasů, které jsou pro ně specifické jakožto pro formy činnosti veřejné správy, a to včetně možností obrany pro př́ípad dotčení na subjektivních právech.

\section{2. ÚPRAVA VEŘEJNOPRÁVNÍCH SOUHLASU゚}

Jak již bylo shora poznamenáno, jedním ze zásadních nov stávajícího stavebního zákona již při jeho prrijetí bylo, že zavedl režimy, v jejichž smyslu lze účelu obecně sledovaného zpravidla věcně př́slušným rozhodnutím dosáhnout za splnění stanovených podmínek v jednodušších případech získáním tzv. souhlasu.

V př́padech své využitelnosti tak dané souhlasy slouží stejnému cíli jako rozhodnutí, jsou jejich náhradou a vydávají se namísto nich, a ve své podstatě jsou také v jistém smyslu i jejich jednodušší alternativou. To přirozeně nemůže platit obecně, zákonodárce může takový jejich režim nastavit jen tam, kde jde o jednoduché a také vcelku jednoznačné situace, a kde se posouzení či ověření podmínek jejich vydání jeví zcela transparentní.

Tak také byly již při přijetí stavebního zákona pro příslušné jednodušší podmínky a situace výslovně koncipovány územní souhlas a souhlas s ohlášenou stavbou jako alternativy územního rozhodnutí a stavebního povolení, kolaudační souhlas dokonce (na několik let) zcela nahradil kolaudační rozhodnutí, dále byl zaveden souhlas se změnou v uživáni stavby jako alternativa rozhodnutí o změně uživání, a do jisté míry obdobně byl zaveden také souhlas $s$ ohlášeným záměrem odstraněni stavby.

Počáteční znění úpravy veřejnoprávních souhlasů přirozeně, jak ostatně již bylo avizováno výše, prošlo od svého přijetí následnými změnami, přičemž její původní znění

4 Charakteristikou veřejnoprávních souhlasů v režimu stavebního zákona, včetně možností jejich přezkumu, se autor tohoto příspěvku již také do určité míry zabýval a vyjadřoval se $\mathrm{k}$ ní, a to ve vícero souvislostech. Viz zejména PRŮCHA, P. K vybraným novým formám činnosti veřejné správy v režimu stavebního zákona. Acta Universatis Carolinae - Iuridica, 2010, č. 1, s. 251-263; PRŮCHA, P. K problematice územního souhlasu. Stavební právo - Bulletin, 2010, č. 1, s. 1-12; PRŮCHA, P. - GREGOROVÁ, J. a kol. Stavebni zákon. Praktický komentár podle stavu k 1. lednu 2017. Praha: Leges, 2017. $\mathrm{V}$ tomto př́íspěvku se potom $\mathrm{z}$ daných dř́vějších autorových vyjádření a stanovisek $\mathrm{k}$ nim vychází a také se na ně navazuje. 
platilo až do přijetí a nabytí účinnosti výše zmíněného zákona č. 350/2012 Sb. Z pohledu obecných, či společných, otázek úpravy předmětných veřejnoprávních souhlasů, přitom byla nejobsažnější úprava ve stavebním zákoně ${ }^{5}$ spojena s územním souhlasem.

Úprava územního souhlasu byla vedena snahou zracionalizovat, zjednodušit a zrychlit dosažení cíle, jinak sledovaného územním rozhodnutím. Úprava stanovila, že územním souhlasem se tam, kde to právní úprava umožňuje, nahrazuje územní rozhodnutí (zákon používá dikci: „Místo územního rozhodnutí může stavební úřad vydat územní souhlas, a to..."). K provedení př́íslušné procedury a k vydání územního souhlasu byl příslušný stavební úřad, a to na základě oznámení příslušného záměru žadatelem. Vlastní vydání územního souhlasu bylo zákonem vázáno na zcela konkrétní determinující podmínky. V prvé řadě platilo, že územní souhlas může být vydán, jen pokud má být daný záměr uskutečněn v zastavěném území nebo v zastavitelné ploše, poměry v území se podstatně nemění, záměr nevyžaduje nové nároky na veřejnou dopravní a technickou infrastrukturu, a současně jestliže předmětný záměr nepodléhal posouzení vlivů na životní prostředí. Podmínkou vydání souhlasu také byly souhlasy osob příp. odlišných od žadatele, které byly vlastníky pozemku, na němž měl být záměr uskutečněn, a dále také souhlasy osob, které měly vlastnická nebo jiná věcná práva k sousedním pozemkům nebo stavbám na nich se společnou hranicí. Právní úprava dále stanovila, že územní souhlas nelze vydat, pokud některé závazné stanovisko dotčeného orgánu, které bylo k záměru vyžadováno, obsahuje podmínky, nebo je-li takovým závazným stanoviskem se záměrem vyjádřen nesouhlas.

Dále bylo také stanoveno, že územní souhlas postačil jen v zákonem taxativně stanovených případech. ${ }^{6} \mathrm{~V}$ průběhu procedury vydání územního souhlasu se nejen $n e-$ konalo veřejné ústní jednání, ale nepřicházelo v úvahu v jejím průběhu ani vypořádání př́padných námitek či připomínek. Procedura vydání územního souhlasu se tak po doručení oznámení o př́íslušném záměru v území k vydání územního souhlasu koncentrovala na posouzení samotného záměru. Stavební úřad poté, co obdržel oznámení o záměru, nejprve zkoumal, zda záměr splňuje zákonem předepsané podmínky pro vydání územního souhlasu. Pokud stavební úřad shledal, že záměr nesplňuje podmínky pro vydání souhlasu, nebo bylo třeba stanovit podmínky pro jeho realizaci, rozhodl do 30 dnů od oznámení záměru usnesením, že se předmětný záměr projedná v územním řízení, a dále se již postupovalo způsobem obvyklým pro běžné územní řizení (př́íp. tzv. zjednodušené) k vydání př́íslušného územní rozhodnutí.

Pokud však stavební úřad naopak shledal, že oznámený záměr v území je v souladu se všemi zákonnými požadavky, potom vydal územní souhlas se záměrem, a to taktéž do 30 dnů ode dne jeho oznámení. Územní souhlas se vyhotovoval a nadále vyhotovuje

5 Podrobnější náležitosti potom u všech v úvahu přicházejících veřejnoprávních souhlasů stanovoval již od počátku této úpravy prováděcí předpis, jímž byla vyhláška č. 503/2006 Sb., o podrobnější úpravě územního rozhodování, územního opatření a stavebního řádu.

6 Jmenovitě se jednalo o prrípady staveb, jejich změn a zařízení, které nevyžadují stavební povolení ani ohlášení, ohlašovaných staveb, jejich změn a zařízení, staveb pro reklamu, staveb umistovaných v uzavřených prostorech existujících staveb, nemění-li se vliv stavby na okolí, úprav terénu, násypů a výkopů do $1,5 \mathrm{~m}$ výšky nebo hloubky, pokud nejsou větší než $300 \mathrm{~m}^{2}$ a nehraničí s veřejnými komunikacemi a veřejnými prostranstvími nebo nedochází-li k nakládání s odpady, skladových, výstavních a manipulačních ploch do $200 \mathrm{~m}^{2}$ mimo vrakoviště a skládek odpadu, změn druhu pozemku o výměře do $300 \mathrm{~m}^{2}$, a dále také u změn staveb. 
písemně, prričemž k územnímu souhlasu stavební úřad připojuje situační výkres, který opatr̂́i ověřovací doložkou.

Územní souhlas, obdobně jako územní rozhodnutí, neměl časově neomezenou platnost. U územního souhlasu právní úprava $\mathrm{v}$ tomto počátečním období platnosti jeho režimu výslovně stanovila, že územní souhlas platil 12 měsíců ode dne jeho vydání, prričemž územní souhlas pozbýval platnosti, pokud nebyla $\mathrm{v}$ této lhủtě podána žádost o stavební povolení, ohlášení nebo žádost o jiné rozhodnutí podle stavebního zákona, atd. Z kontextu právní úpravy bylo za tohoto stavu věci možné dovodit, že jeho účinky nastávaly jeho doručením oznamovateli záměru, a již z povahy věci tak bylo také vyloučeno odvolání.

Již tento stručný pohled na podmínky a proceduru vydání územního souhlasu dostatečně dokládá zjevné rozdíly oproti územnímu řízení, vyúst'ujícímu v územní rozhodnutí. Ve spojení s tím bylo, a to zejména ve správně-právní praxi, dovozováno, že se v prrípadě územních souhlasů jedná o úkony podle části čtvrté správního řádu, a nikoliv o rozhodnutí, podřaditelné části druhé správního řádu.

Poněkud úsporněji stavební zákon v daném období upravoval režim souhlasu s ohlášenou stavbou. ${ }^{7} \mathrm{~V}$ porovnání s režimem územního souhlasu se nabízí připomenout, že právní úprava souhlasu s ohlášenou stavbou v daném období počítala vedle reálného vydání souhlasu v písemné formě dále také s tzv. fikcí udělení souhlasu. Právní úprava výslovně stanovila, že pokud stavebníkovi nebyl doručen souhlas do 40 dnů ode dne, kdy ohlášení došlo stavebnímu úřadu, a ani mu nebyl v této lhůtě doručen zákaz provedení ohlášeného stavebního záměru, platilo, že stavební úřad souhlas udělil.

Jinak obdobně jako u územního souhlasu byla stanovena doba platnosti tohoto souhlasu, tedy 12 měsíců, $\mathrm{s}$ tím, že souhlas platnosti nepobyl, pokud bylo v této době s ohlášenou stavbou započato. Předmětná lhůta počínala běžet dnem následujícím po dni, kdy byl stavebníkovi souhlas doručen, a v príípadě souhlasu fikcí dnem následujícím po dni, kdy uplynulo 40 dnů od ohlášení záměru.

Z uvedeného je taktéž zrejmé, že i tady bylo již z povahy věci vyloučeno odvolání, a i u těchto souhlasů se zcela zjevně jednalo o úkony podřaditelné části čtvrté správního řádu.

Další ze souhlasů, a to kolaudační souhlas, nebyl v tomto období platnosti stavebního zákona, na rozdíl od ostatních souhlasů, pojat jako alternativa kolaudačního rozhodnutí pro jednodušší prrípady a situace, nýbrž naopak (v porovnání s úpravou předchozí) jako náhrada kolaudačního rozhodnutí.

Stávající stavební zákon při svém přijetí institut kolaudačního rozhodnutí opustil (vrátil se k němu až po účinnosti zákona č. 225/2017 Sb.), nicméně z úpravy kolaudačního souhlasu bylo již tehdy zřejmé, že i v tomto př́ípadě se jednalo o úkon nemající formu správního rozhodnutí. Právní úprava stanovila výslovně, že kolaudační rozhodnutí není správním rozhodnutím, a i tady tak bylo nutné dovodit, že se i v případě kolaudačních souhlasů jedná o úkony podle části čtvrté správního řádu.

Pokud šlo o souhlas se změnou v užívání stavby, ten přicházel při splnění stanovených podmínek v úvahu k oznámení vlastníka stavby či jinak oprávněné osoby. Platilo

7 To do jisté míry odráželo skutečnost, že režim ohlášení stavby byl znám i předchozímu stavebnímu zákonu. 
přitom, že souhlas bylo možné bud'to udělit písemně, a to ve lhůtě 30 dnů od oznámení záměru změny užívání stavby, nebo mohl souhlas nastat také fikcí. Ta nastala tehdy, pokud stavební úřad ve lhůtě 30 dnů od oznámení změny v užívání stavby její užívání nezakázal. $\mathrm{V}$ takovém prípadě se tedy marným uplynutím předmětné 30 denní lhůty mělo za to, že stavební úrăad se změnou v uživání stavby souhlasí.

Současně již od přijetí stavebního zákona platilo, že pokud se změna v užívání dotýkala práv třetích osob nebo vyžadovala podrobnější posouzení, stavební úřad souhlas udělit nemohl, a v předmětné lhůtě 30 dnů vyrozuměl oznamovatele, že změna v uživání podléhá rozhodnutí, a zároveň určil podklady nezbytné pro ř́zení. Jejich předložením pak došlo k zahájení řízení o změně $\mathrm{v}$ užívání stavby.

$\mathrm{V}$ případě vydaných souhlasů se změnou $\mathrm{v}$ užívání stavby, obdobně jako $\mathrm{v}$ př́ípadech předchozích, bylo i tady nutno dovozovat, že se jedná o úkony podle části čtvrté správního řádu.

Shora bylo poznamenáno, že stávající stavební zákon již od svého přijetí počítal také se souhlasem s odstraněním stavby. Specifikem tohoto souhlasu bylo, že až do novelizace provedené zákonem č. 350/2012 Sb. jeho vydání přicházelo v úvahu toliko fikcí. Podle výslovného tehdejšího znění právní úpravy platilo, že stavbu bylo možné odstranit, pokud stavební úřad do 30 dnů ode dne ohlášení záměru odstranit stavbu nesdělil, že k jejímu odstranění je třeba povolení.

Vzhledem $\mathrm{k}$ tomu, že právní fikce není úkonem, resp. v našem případě správním úkonem, nýbrž je uměle vytvořenou právní konstrukcí, s předvídanými účinky, nepřichází u ní v úvahu ani podřazování jejich důsledku diferenciaci forem úkonů dle správního řádu.

Takto koncipovaná právní úprava veřejnoprávních souhlasů $\mathrm{v}$ režimu stavebního zákona platila, jak již bylo shora poznamenáno, až do nabytí účinnosti její novelizace provedené zákonem č. 350/2012 Sb., tj. do konce roku 2012. Po tomto datu pak až do účinnosti zákona č. 225/2017 Sb., daná úprava platila ve znění předmětné novelizace.

U úpravy územního souhlasu došlo novelizací provedenou zákonem č. 350/2012 Sb. $\mathrm{k}$ jejímu vícerému upřesnění či doplnění. Vedle terminologické změny, kdy namísto oznámeni o záměru zákonná úprava začala hovořit o žádosti o územni souhlas, je třeba poukázat zejména na její další upřesnění či doplnění.

Především bylo výslovně stanoveno, že se územní souhlas neprojednává v územním řízení, a ve spojení s tím bylo také výslovně zdůrazněno, že se na vydávání územního souhlasu nevztahují část druhá a třetí správního řádu.

Současně bylo také výslovně stanoveno pravidlo pro přezkoumání územního souhlasu v přezkumném řízení. Zatímco do té doby bylo výkladem zpravidla dovozováno, že územní souhlas lze přezkoumat $\mathrm{v}$ režimu přezkumného řízení předepisovaného pro úkony podle části čtvrté správního řádu (§ 156 správního řádu), od 1. 1. 2013 potom výslovně platilo, že územní souhlas lze přezkoumat $\mathrm{v}$ přezkumném řízení, které lze zahájit do 1 roku ode dne, kdy územní souhlas nabyl právních účinků, a rozhodnutí ve věci v přezkumném řízení v prvním stupni nelze vydat po uplynutí 15 měsícủ ode dne, kdy územní souhlas nabyl právních účinků. Nicméně výkladově otevřenou otázkou zůstalo, který správní orgán je, či byl, k př̌zkoumání územního souhlasu př́slušný (orgán, který souhlas vydal, či orgán jemu nadř́zený). 
Nově byl jako limit pro vydání územního souhlasu stanoven také souhlas dalších dotčených osob, odlišných od osob tzv. mezujících. Tzn. i příp. takových dotčených osob, které s předmětným pozemkem, ve vztahu $\mathrm{k}$ němuž mířil daný územní souhlas, společnou hranici neměly. K vydání územního souhlasu se tak nově začal vedle souhlasu mezujících dotčených osob vyžadovat i souhlas prríp. nemezujících dotčených osob. Bez tohoto souhlasu muselo být přistupováno k územnímu řízení.

A konečně další zřetelehodnou změnou bylo, že byla prodloužena doba platnosti územního souhlasu na 2 roky ode dne jeho vydání.

Zákonem č. 350/2012 Sb. byl dále nově zaveden společný územní souhlas a souhlas s provedením ohlášeného stavebního záměru. Podle daného znění právní úpravy vydání tohoto společného souhlasu přicházelo $\mathrm{v}$ úvahu tehdy, resp. $\mathrm{v}$ těch případech, kdy stavebník podal současně žádost o územní souhlas (§ 96 odst. 3) a také i ohlášení stavebního záměru (§105), které splňovaly požadavky na vydání obou př́í. jednotlivých souhlasů. $Z$ obsahu předmětné právní úpravy prritom bylo zřejmé, že při splnění předepisovaných zákonných požadavků takto stavební úřad postupovat měl či musel (arg. ,vydá“ společný souhlas), a nikoliv, že by vydání společného souhlasu byla v uvedených př́ípadech pro stavební úruad toliko „možnost“ ponechaná na jeho úvaze.

Pro povahu tohoto souhlasu, i proceduru jeho vydání platilo obdobně to, co bylo stanoveno u územního souhlasu, přičemž po obsahové či věcné stránce musely být současně splněny jak požadavky na vydání územního souhlasu, tak požadavky na vydání souhlasu s provedením ohlášeného stavebního záměru.

Společný souhlas, a to obdobně jako $\mathrm{v}$ případě samostatného územního souhlasu, nabýval právních účinků dnem doručení stavebníkovi a platil po dobu 2 let ode dne jeho vydání. Uplynutím uvedené doby platnosti nepozbyl tehdy, pokud bylo v této době s ohlášeným stavebním záměrem započato.

Zavedení společného územního souhlasu a souhlasu s provedením ohlášeného stavebního záměru tak, a to ještě více či dále, naplňovalo výše připomenutý záměr stavebního zákona vyjádřený v jeho $\S 4$ odst. 1 o přednostním využívání zjednodušujících postupů.

Pokud šlo o samotný souhlas s provedením ohlášeného stavebního záměru, jeho úprava po novelizaci stavebního zákona provedené zákonem č. 350/2012 Sb., vedle skutečnosti, že nadále již nebyl možný souhlas na základě fikce, dále doznala prakticky shodných upresnění či doplnění jako úprava územního souhlasu.

$\mathrm{V}$ př́ípadě kolaudačního souhlasu potom změna jeho právního režimu v důsledku předmětné novelizace přinesla zejména také obdobná upřesnění, jako u územního souhlasu a u souhlasu s provedením ohlášeného stavebního záměru.

Úprava souhlasu se zménou v uživání stavby po nabytí účinnosti zákona č. 350/2012 Sb. potom v prvé řadě opustila konstrukci, v jejímž smyslu bylo možné do té doby daného souhlasu nabýt právní fikcí, a dále byla formulačně upřesněna otázka vlivu dotčenosti tzv. třetích osob. Nově byla zvolena formulace, že podmínkou vydání tohoto souhlasu je, že se změna v účelu užívání nedotýká práv třetích osob.

Návazně potom změna úpravy i u tohoto souhlasu výslovně přinesla pravidla jako u územního souhlasu a souhlasu a souhlasu s provedením ohlášeného stavebního záměru, pokud šlo limitaci využitelnosti správního řádu a přezkumné řízení. 
U souhlasu s odstraněním stavby potom daná změna právní úpravy zvolila téměř identickou cestu jako v př́ípadě souhlasu se změnou v užívání stavby. Taktéž byla opuštěna konstrukce umožňující nabytí tohoto souhlasu právní fikcí (v tomto případě do té doby jako výlučná možnost „,souhlasu“), a nově bylo možné naopak tento souhlas získat již jen výslovným projevem stavebního úřadu. Dále bylo výslovně taktéž stanoveno, že souhlas byl vázán na podmínku, že se záměr nedotýkal práv třetích osob. Další posun potom znamenalo i u tohoto souhlasu zavedení obdobných pravidel stran využitelnosti správního řádu a podmínek přezkumného řízení.

Dosud poslední změny v úpravě veřejnoprávních souhlasů v režimu stavebního zákona přinesla jeho novelizace provedená zákonem č. 225/2017 Sb., a to s účinností od 1. 1.2018.

Z úhlu pohledu, který je sledován $v$ tomto př́spěvku, tj. zaměření na ty otázky či aspekty, které jsou pro předmětné veřejnoprávní souhlasy specifické jakožto pro formy činnosti veřejné správy, a to včetně možností obrany pro př́ípad dotčení na subjektivních právech, lze poznamenat, že převážně tato novelizace přinesla zejména některá terminologická a formulační upřesnění. Tak lze např. poznamenat, že stavební zákon, který v bezprostředně v předchozím znění, a to v mezidobí od 1. 1. 2013 do konce roku 2017, hovořil o žádosti o vydání územního souhlasu, se znovu od nabytí účinnosti jeho novelizace, provedené zákonem č. 225/2017 Sb., tj. od 1. 1. 2018, vrátil k dikci „oznámení záměru“, kterou (jako „oznámení o záměru“) znal a užíval stavební zákon již před jeho novelizací provedenou zákonem č. 350/2012 Sb. Př́slušná prováděcí úprava, tj. vyhláška č. 503/2006 Sb., potom byla v této souvislosti (tj. v souvislosti s nabytím účinnosti zákona č. 225/2017 Sb.), novelizována vyhláškou č. 66/2018 Sb.

Za nejpodstatnější změnu, která se týkala úpravy v podstatě všech předmětných veřejnoprávních souhlasů, lze potom označit to, že byl upřesněn režim přezkumného ř́zení ve vztahu k předmětným souhlasům, a to tak, že byl jmenovitě určen či označen správní orgán, př́íslušný $\mathrm{k}$ danému přezkumnému rrízení. Právní úprava takto stanovila, že k přezkumnému řízení je příslušný správní orgán nadřizený stavebnímu úřadu, který souhlas vydal.

Tím byly odstraněny předchozí pochybnosti, který správní orgán je $\mathrm{k}$ danému přezkumnému řízení příslušný. Výslovná úprava přezkoumání veřejnoprávních souhlasů v režimu stavebního zákona byla, jak bylo již také shora poznamenáno, zavedena novelizací stavebního zákona provedenou zákonem č. 350/2012 Sb., s účinností od 1. 1. 2013. Odborná praxe se přitom různila $\mathrm{v}$ názorech, podle jaké části správního rrádu měl tento přezkum probíhat a úřad jaké instituce by jej měl provádět. Výkladové nejasnosti vyvolávalo zejména použití pojmu ,přezkumné řízení“ a „rozhodnutí ve věci v přezkumném řízení“. Část praxe se klonila k názoru, že se nejedná o přezkumné řízení podle $\S 94$ až 99 správního rádu, a že se na dané přezkumné rízení uplatní $§ 156$ odst. 2 $\mathrm{z}$ části čtvrté správního rádu, a to včetně toho, že $\mathrm{v}$ daném přezkumném řízení, $\mathrm{k}$ němuž je př́slušný orgán, který předmětný souhlas vydal, se má rozhodovat usnesením a jedinou možností v prípadě zjištění rozporu přezkoumávaného souhlasu se zákonem je daný souhlas zrušit.

Opačný názor zastával např. veřejný ochránce práv, který dovodil, že přezkum podle části čtvrté správního řádu nebyl zcela funkční a neodpovídal principům dobré správy, 
a to zejména proto, že takový přezkum by měl zajistit tentýž úřad, který souhlas vydal. Argumentoval, že na základě souhlasu, ač není formálně správním rozhodnutím, vznikají konkrétní hmotná práva. Podle ochránce mělo být k přezkumu souhlasu proto přistupováno obdobně jako v prŕípadě správního rozhodnutí. ${ }^{8}$

Novelizace stavebního zákona provedená zákonem č. 350/2012 Sb. sice výslovně hovořila o tom, že na vydání souhlasu se nevztahuje část druhá a třetí správního řádu, ale z toho bylo možno jednoznačně dovodit pouze to, že je souhlas tzv. ,jiným aktem“ ve smyslu § 154 správního řádu. Současné doplnění pravidla, že přezkum souhlasu bude probíhat v ,přezkumném řízení“", však podle této výkladové teorie vedlo k závěru, že přezkum bude probíhat v „klasickém“ přezkumném řízení dle ustanovení $§ 94$ a násl. správního řádu. K tomuto závěru dospěl také Krajský soud v Praze ve svém rozsudku ze dne 22. 10. 2015, čj. 48 A 27/2015-98, když uvedl, že ,[s]oud zpravidla nemưže stavebnímu úřadu uložit povinnost kolaudační souhlas zrušit, nebot’od 1. 1. 2013 se souhlasy podle stavebního zákona ruši či mění v ,klasickém ' přezkumném řízení, kde pravomoc zrušit či změnit souhlas náleži podle §95 odst. 1 správního řádu z roku 2004 nadřizenému správnímu orgánu. "Obdobný právní názor byl publikován i v odborné literatuře. ${ }^{9}$

V současné době je potom tento právní názor již v důsledku předmětné novelizace s účinností od 1. 1. 2018 aprobován i legislativně.

$\mathrm{Z}$ dalších zrretelehodných změn je třeba také poznamenat, novelizace stavebního zákona výrazněji zasáhla do režimu kolaudačního souhlasu, a to tak, že jej, a to z pohledu jeho postavení v režimu kolaudace, postavila po jedenácti letech na roveň ostatním veřejnoprávním souhlasům, tj. jako alternativu ke kolaudačnímu rozhodnutí, a to tam, kde se jednalo či jedná o př́íslušné jednodušší stavební podmínky a situace. V mezidobí od počátku účinnosti stavebního zákona až do 1. 1. 2018 platilo, že stavební zákon kolaudační rozhodnutí, na rozdíl od předchozí úpravy, jako takové opustil, a za kvalifikovanou formu aktu osvědčující provedenou kolaudaci označil právě kolaudační souhlas. Nicméně po celou tuto dobu byl kolaudační souhlas svými obsahovými i formálními znaky stavěn na roveň ostatním veřejnoprávním souhlasům (které alternativou k příslušným rozhodnutím byly), a toto zůstalo v platnosti i poté, co se stavební zákon ke kolaudačnímu rozhodnutí vrátil (to pro případy složitějších stavebních podmínek a situací).

Po nabytí účinnosti novelizace stavebního zákona, provedené zákonem č. 225/2017 Sb., již právní režim veřejnoprávních souhlasů (dosud) novelizován nebyl, a dá se s jitou mírou zobecnění říci, že co do jejich charakteristiky jako forem činnosti veřejné správy jde, ve smyslu takto aktuálního znění právní úpravy, o akty s procesní povahou správních úkonů podřaditelných úpravě části čtvrté správního řádu. Jedinou výjimkou v tomto směru je u nich odlišná výslovná úprava jejich přezkumného řízení, které je opisem nastaveno principiálně obdobně, jako přezkumné řízení upravené v části druhé správního řádu. To zcela zjevně, byt' poněkud asymetricky, koresponduje potřebám zajištění kvalifikovanějších podmínek efektivní veřejnosprávní obrany osob, které mohou být předmětnými souhlasy příp. nezákonně dotčeny na svých subjektivních právech.

\footnotetext{
Viz zpráva ochránce o šetření z vlastní iniciativy ze dne 12. 5. 2014, sp. zn. 4101/2013/VOP.

9 VEDRAL, J. Přezkum souhlasů stavebních úřadů po novele stavebního zákona. Stavební právo, bulletin, 2013, č. 2, s. 23 a násl.
} 


\section{SPRÁVNĚ-SOUDNÍ REFLEXE}

Verejnoprávní souhlasy $\mathrm{v}$ režimu stavebního zákona přitom již od počátku této jejich výslovné zákonné úpravy nebyly bezezbytku vyloučeny ani z předmětu zájmu praxe správního soudnictví. Nutno však poznamenat, že v dosavadním průběhu platnosti stavebního zákona došel i jejich správně-soudní přezkum také poměrně specifickým vývojem.

V počáteční době po nabytí účinnosti nynějšího stavebního zákona se z pohledu právní úpravy obsažené ve správním řádu vzhledem $k$ povaze předmětných veřejnoprávních souhlasů, jakož i vzhledem k proceduře, která byla pro jejich vydání stanovena, nabízel závěr, že předmětné souhlasy jsou úkony podle části čtvrté správního řádu (upravující tzv. vyjádření osvědčení, sdělení, aj. úkony, odlišné od rozhodnutí). V této souvislosti je však třeba poznamenat, že vzdor prakticky bezvýhradné ustálenosti názoru v př́śslušné odborné literatuře, ${ }^{10}$ že dané souhlasy jsou takovými akty či úkony, se na počátku roku 2009 poněkud překvapivě objevil zcela jiný názor ve správně-soudní judikatuře. Nejvyšší správní soud (dále jen „NSS“) ve svém rozsudku ze dne 22. 1. 2009, čj. 1 As 92/2008-76, jmenovitě vyjádřil právní názor, že územní souhlas je rozhodnutím ve smyslu části druhé správního řádu a mělo u něj přicházet v úvahu odvolání. Právní věta tohoto rozsudku zní: „Územní souhlas vydaný na základě § 96 stavebního zákona z roku 2006 je rozhodnutím ve smyslu § 67 odst. 1 správního ŕádu z roku 2004, a proto je odvoláni proti němu prípustné. Sděleni odvolacího orgánu, kterým byly námitky vznesené proti územnímu souhlasu shledány neopodstatněnými, je třeba považovat z materiálního hlediska za rozhodnutí o odvoláni.““

Právní názor, že územní souhlas je rozhodnutím ve smyslu části druhé správního řádu a mělo u něj přicházet v úvahu odvolání, nebyl ani rozhodovací praxí, ani odbornou literaturou přijat bez rozpaků, a tudíž ani jednotně, přičemž po mém soudu spíše převládlo nesouhlasné hodnocení. ${ }^{11} \mathrm{Z}$ právní úpravy územního souhlasu, ostatně stejně jako z právní úpravy ostatních veřejnoprávních souhlasů, přitom poměrně zřetelně vyplývalo, že tyto souhlasy nabývaly svých právních účinků bezprostředně v návaznosti na jejich vydání, a tudíž žádné odvolání v úvahu přicházet nemohlo.

Současně nemůžeme pominout, že předmětný judikát se výslovně vyjádřil i k soudní přezkoumatelnosti předmětných veřejnoprávních souhlasů, resp. v tomto př́ípadě výslovně jen k souhlasu územnímu. Tady dospěl k závěru, že dané rozhodnutí o odvolání, které je rozhodnutím ve smyslu $\$ 65$ s. r. s., a neni tedy vyloučeno ze soudního přezkumu dle $\$ 70$ pism. a) s. r. s. Pokud ale u souhlasů žádné odvolání v úvahu nepřicházelo, potom bylo poněkud mimoběžné se zabývat povahou rozhodnutí o něm. Spíše se nabízelo uvažovat $\mathrm{o}$, a vyjádřit se $\mathrm{k}$ soudní přezkoumatelnosti samotných veřejnoprávních

10 Např. MAREK, K. - PRŮCHA, P. Nové stavební právo. Brno: Masarykova univerzita, 2007, s. 89 a násl.; STAŠA, J. Správní postupy podle nového stavebního zákona. In: Ochrana životního prostředí ve správním soudnictví, Praha: LexisNexis CZ, Kroměříž: Justiční akademie, 2008, s. 42, 47; dále DOLEŽAL, J. - MAREČEK, J. - SEDLÁČKOVÁ, V. - SKLENÁR̆, T. - TUNKA, M. - VOBRÁTILOVÁ, Z. Nový stavebni zákon v teorii a praxi. Praha: Linde, 2006, s. 188 a násl.; HEGENBART, M. - SAKA Ř, B. a kol. Stavební zákon. Komentár. Praha: C. H. Beck, 2008, s. 96 a násl.

11 Z odborné literatury srov. např. VEDRAL, J. K právní povaze územního souhlasu. Stavební právo, bulletin, 2009, č. 1-2, s. 23 a násl. 
souhlasů, resp. v daném př́ípadě $\mathrm{k}$ soudní přezkoumatelnosti souhlasu územního. To však daný judikát ponechal stranou svého výslovného zájmu.

Nabízí se přitom poznamenat, že v dané době správně-soudní judikatura většinově považovala za přezkoumatelné i takové úkony či akty správních orgánů, které po formální stránce rozhodnutími nebyly, nicméně u kterých šlo o rozhodnutí v materiálním slova smyslu. Ve správním soudnictví tak byly jako „rozhodnutí“ přezkoumávány i tzv. jiné správní úkony, které v materiálním slova smyslu zasahovaly do právního postavení dotčených subjektů, i když formálně, tj. ve smyslu požadavků správního ráádu na správní rozhodnutí, rozhodnutími nebyly. To ostatně platilo i o pro úkony, obdobné dnešním veřejnoprávním souhlasům, s nimiž počítal prèedchozí stavební zákon. ${ }^{12} \mathrm{~A}$ tomu bezesporu také odpovídal i územní souhlas, a stejně tak i ostatní veřejnoprávní souhlasy, a to, zdá se zcela zřejmě již od přijetí stávajícího stavebního zákona.

Bylo tedy více méně jen otázkou času, kdy na tento soudní závěr bude reagováno jinou judikaturou, popř. i změnou legislativy.

Závěry uvedeného judikátu zcela zjevně správní praxi, a to i bez ohledu na jejich problematičnost vzhledem $\mathrm{k}$ danému znění předmětné právní úpravy, nevyhovovaly, což bylo i jedním z impulsů $\mathrm{k}$ legislativní reformulaci dotčených ustanovení stavebního zákona. Vyústěním těchto legislativních snah potom bylo přijetí zákona č. 350/2012 Sb., který ve sledovaných souvislostech zejména přinesl výslovnou změnu v tom, že stanovil, že na jejich vydávání se nevztahuji část druhá a třetí správního řádu, souhlasy nabývaji právních účinků dnem jejich doručení žadatelům, a že o námitkách dotčených osob se nerozhoduje.

Tato novelizace stavebního zákona tak v podstatě vyloučila aplikovatelnost právních závěrů shora uváděného rozsudku NSS ze dne 22. 1. 2009, čj. 1 As 92/2008-76. Předmětná novelizace byla schválena dne 19.9. 2012 a nabyla účinnosti 1. 1. 2013, přičemž její návrh byl praxi znám, a také v ní diskutován již před jejím prrijetím. Zdálo se tak, že pro režim soudního přezkoumávání předmětných veřejnoprávních souhlasů to bude znamenat, že dané souhlasy budou tzv. přímo soudně přezkoumatelné jak tzv. rozhodnutí v materiálním slova smyslu.

Nicméně souhrou okolností den před přijetím této novelizace stavebního zákona bylo ve vztahu k veřejnoprávním souhlasům v režimu stavebního zákona (tedy nejen ve vztahu k územnímu souhlasu, jako tomu bylo v prŕípadě předchozího rozhodnutí) přijato rozhodnutí rozššŕeného senátu Nejvyššího správního soudu ze dne 18. 9. 2012, čj. 2 As 86/2010-76, které také anulovalo aplikovatelnost právních závěrů shora uváděného rozsudku NSS, to však ale ve zcela jiném směru, resp. s jinými důsledky, než připomenutá novelizace stavebního zákona.

Toto rozhodnutí především výslovně opustilo materiální nazírání na povahu předmětných souhlasů, a vyloučilo tak jejich přezkoumatelnost jako rozhodnutí ve smyslu

12 Např. v rozsudcích ze dne 26. 6. 2008, čj. 4 Aps 7/2007-54 a ze dne 10. 7. 2008, čj. 4 As 64/2007-65 Nejvyšší správní soud výslovně uvedl, že souhlasné sdělení stavebního úřadu je rozhodnutím v materiálním slova smyslu, a tedy rozhodnutím ve smyslu $§ 65$ odst. $1 \mathrm{~s}$. ř. s. V obou př́ípadech se jednalo o souhlas vydaný podle stavebního zákona z r. 1976. 
$\S 65$ odst. 1 s. ř. s., a pro soudní ochranu práv třetích osob je nabídlo žalobní režim na ochranu před nezákonným zásahem. ${ }^{13}$

K tomu se nabízí poznamenat, že tento posledně citovaný judikát naproti tomu nikterak nezpochybnil, že se u daných souhlasů jedná o úkony podřaditelné (byt’ zprostředkovaně, ale přesto) části čtvrté správního řádu. V tom se tedy daný judikát také nedostal do kolize s prakticky časově souběžně naběhnuvší novelizací stavebního zákona provedenou zákonem č. 350/2012 Sb., která uváděnou povahu předmětných souhlasů oproti předcházející dikci dotčené úpravy nejen zachovala, ale ještě ji v tomto směru učinila určitější a jednoznačnější.

Daná situace tak navodila hned několik otázek. Za prvé, posílila tato změna ochranu subjektivních práv a jevila se efektivnější, za druhé, změnilo se z pohledu provedené novelizace stavebního zákona něco na uvedeném právním závěru citovaného judikátu, a konečně za třetí, nedošlo opuštěním materiálního nazírání na rozhodnutí jen $\mathrm{k}$ dalšímu dílčímu nežádoucímu vybočení judikatury?

K prvé z uvedených otázek myslím bylo hned od počátku zřejmé, že tato změna judikaturního nazírání na soudní přezkum aktů, které sice po materiální stránce nesou povahu rozhodnutí, po stránce formální však nikoliv, soudní ochranu subjektivních práv neposílila, a nemohla být tedy v tomto smyslu nijak efektivnější. Přijatý judikaturní právní názor nabídl soudní ochranu cestou žaloby proti nezákonnému zásahu, a navíc toliko tzv. třetím osobám. Již zběžný pohled na úpravu soudního přezkumu rozhodnutí a soudního přezkumu nezákonného zásahu však ukazuje, že první z uvedených režimů je komfortnější a může také vyústit v bezprostřední zrušení nezákonného rozhodnutí. $\mathrm{V}$ př́padě nezákonného zásahu lze naproti tomu soudem toliko rozhodnout o povinnosti správního orgánu od nezákonného zásahu upustit, a zajistit nepokračování v něm. Tzn. že efektu se žalobce mohl dočkat podstatně později, a nikoliv v možném dopadu zrušovacího rozhodnutí soudu, ale až následně při eventuální návazné činnosti správního orgánu, což navíc bylo s ohledem na časové relace režimu správního přezkumu i obtížně realizovatelné.

Pokud jde o druhou ze shora nastolených otázek, pro odpověd’ na ni platí do značné míry obdobně to, co bylo konstatováno výše. Daná novelizace stavebního zákona uváděnou povahu předmětných souhlasů jako rozhodnutí v materiálním slova smyslu oproti předcházející dikci dotčené úpravy nejen zachovala, ale ještě ji v tomto směru učinila určitější a jednoznačnější. Tzn. že pomyslné „nůžky“ se ještě o něco více rozevřely, a pokud by judikatura setrvala na prezentovaném prŕistupu, potom se nutně daný kontrast jevil ještě o něco ostřeji.

13 „Souhlasy vydávané dle zákona č. 183/2006 Sb., o územním plánování a stavebním rádu (stavebni zákon), zejména dle §96, § 106, § 122 a § 127, které stavebni úr̆ad výslovně či mlčky činí k ohlášení či oznámení, jsou jinými úkony dle části čtvrté správniho rádu (č. 500/2004 Sb.). Tyto souhlasy nejsou rozhodnutími ve smyslu § 65 soudního rádu správniho; soudni ochrana práv tretích osob je zaručena žalobou na ochranu před nezákonným zásahem, pokynem nebo donucením správního orgánu dle § 82 posledně citovaného zákona. Žadatel o vydání souhlasu či oznamovatel může být v soudním řizení správním, vedeném na základě žaloby třetí osoby napadajici tento souhlas, v postaveni osoby zúčastněné na řizení dle § 34 s. r. s. “ (Podle usnesení rozšířeného senátu NSS ze dne 18. 9. 2012, čj. 2 As 86/2010-76.) 
Ve vztahu ke třetí výše naznačené otázce stran vhodnosti opuštění materiálního nazírání na povahu soudně přezkoumávaných aktů jako rozhodnutí lze myslím již jen stručně konstatovat, že právě $\mathrm{s}$ ohledem na shora uvedené jen návrat $\mathrm{k}$ němu mohl znamenat nejen posílení, ale především již samotné zajištění potřebné efektivnosti soudní ochrany.

Ani tyto právní závěry rozšîřeného senátu NSS správně právní praxi, a zejména pak požadavkům na efektivní ochranu subjektivních práv dotčených subjektů nevyhovovaly, a proto se i za tohoto stavu věci hledalo dílem legislativní, a nutno přiznat, že dílem i judikatorní řešení.

V legislativní rovině, z pohledu možného posílení efektivnosti soudní ochrany, $\mathrm{k}$ př́ilišným změnám nedošlo. Novelizací stavebního zákona provedenou zákonem č. 225/2017 Sb., lze, v uvedeném směru, za nejpodstatnější změnu, která se týkala úpravy v podstatě všech předmětných veřejnoprávních souhlasů, označit to, že byl upřesněn režim přezkumného řízení ve vztahu k předmětným souhlasům, a to tak, že byl jmenovitě určen či označen správní orgán, př́islušný k danému přezkumnému řízení. Právní úprava takto stanovila, že $\mathrm{k}$ přezkumnému řízení je příslušný správní orgán nadřízený stavebnímu úřadu, který souhlas vydal. Tím se však jen částečně vyjasnilo, jak postupovat poté, co správní soud prííp. označí žalovaný souhlas za nezákonný zásah.

Daleko za podstatnější lze potom podle mého názoru označit prŕstup judikatury. Je nutno poznamenat, že mezi správními soudci postupně sílil názor o potřebě překonat závěry rozhodnutí rozšířeného senátu NSS ze dne 18. 9. 2012, čj. 2 As 86/2010-76, a proto také byly nově podány návrhy na jejich přehodnocení.

$\mathrm{K}$ tomu pak skutečně došlo, a to usnesením rozšířeného senátu NSS ze dne 17. 9. 2019, čj. 1 As 436/2017-43, v němž byl formulován právní závěr, že „[s]ouhlasy vydávané stavebním úradem, zejména podle §96, § 106, §122, § 127 a § 128 zákona č. 183/2006 Sb., o územním plánování a stavebním rádu, jsou rozhodnutími správního orgánu dle $\$ 65$ odst. 1 s. r. s. ““

Aniž by bylo myslím při této př́ležitosti třeba podrobněji rozebírat a hodnotit odůvodnění tohoto usnesení, lze po mém soudu souhrnně konstatovat, že takovéto rozhodnutí lze nanejvýš přivítat. Myslím, že jím byla ve své podstatě překonána všechna výše deklarovaná negativa předchozího rozhodnutí rozšsiřeného senátu, a daleko přiléhavěji tento nový, resp. poslední, právní názor odpovídá účelu i dikci předmětné právní úpravy.

Výsledný právní názor, či závěr, jak je ostatně dovoditelné z odůvodnění předmětného usnesení, je dílem reakcí z v mezidobí provedené novelizace stavebního zákona, a dále pak zejména výrazem zřejmého přehodnocení východisek právního názoru předchozího.

Jasným, a to at' již př́mým či zprostředkovaným poselstvím tohoto v pořadí posledního rozhodnutí rozšířeného senátu NSS k předmětné problematice, tj. k problematice veřejnoprávních souhlasů $v$ režimu stavebního zákona, je několik dílčích závěrů. Především z něj lze spolehlivě dovodit, že $\mathrm{k}$ ochraně prííp. dotčených subjektivních práv, a to již vzhledem k povaze těchto aktů jako forem činnosti veřejné správy, neslouží odvolání, a také ani námitky, a podmínkou př́ístupu k soudní ochraně tak není jejich předchozí vyčerpání. Dále lze dané souhlasy veřejnosprávně přezkoumat $\mathrm{v}$ transparentním režimu přezkumného řízení. A konečně, soudní přezkum těchto souhlasů podléhá 
plně kvalifikovanému režimu soudního přezkumu rozhodnutí, a to v souladu s jejich zcela zřetelnou prrítomností materiálních znaků jako rozhodnutí.

Za tohoto stavu věci, kdy jistě nelze vyloučit, že v jednotlivostech mohou být závěry a odůvodnění předmětného usnesení rozšiřeného senátu relativizovány, je po mém soudu jako rozhodující nutno vnímat především to, že dané rozhodnutí přineslo zcela jednoznačnou, a po mém soudu také jedinou správnou odpověd' na základní otázku rozhodující o efektivnosti ochrany dotčených subjektivních práv. Tzn. že tyto nejaktuálnější závěry judikatury $\mathrm{k}$ veřejnoprávním souhlasům lze mít za plně uspokojivé vyústění celého předchozího judikatorního vývoje.

\section{ZÁVĚREM}

Veřejnoprávní souhlasy v režimu stavebního zákona jsou ve své podstatě tzv. zjednodušujícími, či zjednodušenými, formami činnosti veřejné správy při aplikaci stavebního práva. Jejich posláním je $\mathrm{v}$ adekvátních jednodušších případech a situacích méně náročným způsobem, a přitom současně dostatečně způsobile, zabezpečit žádoucí subjektivizaci veřejného stavebního práva. $\mathrm{K}$ tomu je ovšem třeba, aby i tyto zjednodušené formy činnosti byly náležitě právně ošetřeny, a to zejména pokud jde o proceduru jejich přijetí, resp. vydání, a to včetně př́slušných garancí ochrany dotčených subjektivních práv.

$\mathrm{Z}$ výše uvedeného přehledu $\mathrm{v}$ tomto př́spěvku se podává, že úprava těchto souhlasů, kterou v daném pojetí a šiři přinesl teprve dnešní stavební zákon s účinností od 1. 1. 2007, prošla od té doby zřetelehodným vývojem, jenž vyústil v její stávající poměrně propracovaný a také jednoznačný stav. Některé z těchto změn právní úpravy přitom byly inspirovány mj. i př́slušnými judikatorními závěry správního soudnictví, které taktéž prošly významným vývojem. I tento vývoj aktuálně dospěl do stavu, který lze považovat za plně adekvátní.

V zásadě tak lze mít za to, že takto vývojem aktuálně dosažený stav právní úpravy veřejnoprávních souhlasů i související správně-soudní judikatury dosud nejadekvátněji naplňuje a také potvrzuje jejich účel, poslání a rovněž i jejich plnou opodstatněnost.

To se potom jako významné jeví zejména v souvislosti se stále naléhavěji artikulovanými požadavky na další zjednodušení a urychlení procedur rozhodování v oblasti veřejného stavebního práva. Současně se takto potvrzuje i teze, že veřejná správa by měla mít k dispozici diferencovanou škálu forem činnosti, aby mohla vždy volit ty z nich, které jsou nejadekvátnější faktické složitosti či obsažnosti řešených otázek v tom kterém prípadě.

Petr Průcha

Právnická fakulta Masarykovy univerzity

petr.prucha@law.muni.cz 